\title{
Junk Food Consumption Among Secondary Level Students, Chitwan
}

\author{
Sapkota SD ${ }^{1}$, Neupane $\mathbf{S}^{2}$
}

\begin{abstract}
Introduction: Junk food is a pejorative term for cheap food containing high levels of calories from sugar or fat with little fibre, protein, vitamins or minerals. This study was conducted to assess the junk food consumption and patterns of consumed junk food among secondary level students. Material and Methods: This was a descriptive cross-sectional research. Hundred forty-two respondents were drawn by using cluster sampling method. Self-administered semi-structured questionnaire in Nepali Version was used and the collected data was entered and analysed in Epi-data and SPSS Version 20 by using simple statistical methods. Results: The findings revealed that more girls $(53.5 \%)$ consumed junk food than boys $(79.6 \%)$ and those respondents were aware of the meaning of junk food. Majority of respondents $(90.1 \%)$ preferred junk food for taste, is faster to prepare $(44.4 \%)$, preferred as influenced by TV advertisements (15.5\%), because of peer influences $(31.7 \%)$ and some $(29.6 \%)$ respondents preferred junk food because nothing else was available. Concerning patterns of consumed junk food all respondents (100\%) consumed 'chat-pat' and noodles, panipuri (97.2\%), doughnuts (93\%), chocolates $(92.3 \%)$, biscuits $(95.8 \%)$, ice cream $(65.5 \%)$ and cold drinks $(65.5 \%)$. Only $54.2 \%$ of respondents were aware of risks associated with poor eating habits. Conclusion: Adolescents consumed a greater amount of junk food which led to a majority of ill effects later on. It is recommended that the school and community conduct and implement awareness programme on junk food consumption and its ill effects.
\end{abstract}

Key words: Junk food, Adolescence

\section{Introduction}

$\mathrm{T}$ he term 'Junk food' was coined as a slang in the public interest in 1972 by Michael Jacobson, Director of the Centre for Science, Washington D.C. Junk food is energy dense food with high amount of refined sugar, white flour, trans-fat, polyunsaturated fat, salt, numerous additives and low nutrient value in terms of protein, fibre, vitamin, and mineral content. Foods like chips, chocolate, soft drink etc. are generally taken as junk food ${ }^{1}$.

Habits start young and depend on the environment (home and
${ }^{1}$ Ms. Shubha Devi Sapkota, MSN. Lecturer, Department of Paediatrics, ${ }^{2} \mathrm{Ms}$. Seema Neupane, BN. Staff Nurse. Both from NPINarayani Samudayik Hospital (College of Nursing), Bharatpur, Chitwan.

\author{
Address for correspondence \\ Shubha Devi Sapkota, MSN. \\ Lecturer, Department of Paediatrics, \\ NPI-Narayani Samudayik Hospital (College of \\ Nursing). \\ Bharatpur, Chitwan, Nepal. \\ Tel: +9779845500600 \\ E-mail: shubhasapkota@gmail.com
}

Acknowledgements: We express our profound gratitude to NPI-Narayani Samudayik Hospital for providing every support needed for the study.

Funding: Nil

Conflict of Interest: This manuscript is a part of compulsary thesis submission for the degree of Bachelor of Nursing submitted to Purbanchal University

Permission from IRB: Yes

\section{How to cite}

Sapkota SD, Neupane S. Childhood Poisoning, Junk Food Consumption Among Secondary Level Students, Chitwan. J Nepal Paediatr Soc 2017;37(2):147-152.

doi:http://dx.doi.org/10.3126/jnps.v37i2.17081

This work is licensed under a Creative Commons Attribution 3.0 License.

(c) (i) 
school primarily) to cultivate healthy habits in children, the school being the next-best home of learning and nurturing. With the rise in the incidence of obesity and overweight amongst youngsters and adults, the darkside of 'junk food' cannot be overlooked. The statistics of America records sixty million deaths every year due to obesity or overweight ${ }^{2}$.

Adolescence is commonly regarded as a relatively healthy period of the life cycle. During this period there are various physical, psychological and behavioural transitions occurs which affect their lifestyle and influences their eating patterns. Eating pattern of adolescents is influenced by many factors including peer influences, parental modeling, food availability, food preferences, cost, convenience, personal and cultural beliefs, mass media, and body image ${ }^{3}$.

Competitive foods are sold through vending machines, school canteens/stores, and fundraisers and, in contrast to the federally-reimbursable school meal programs against federal nutritional standards. They are available in a large share of schools, although the availability of these foods varies significantly. For example, as many as $97 \%$ of high schools and $82 \%$ of middle schools have vending machines compared to only $17 \%$ of elementary schools ${ }^{4}$.

Among 1000 college adolescents, significantly greater numbers of boys $15 \%$ as compared to girls $10.2 \%$ were overweight. Out of the total obese children, $82.3 \%$ were non-vegetarian, whereas only $8.8 \%$ of vegetarians and ova vegetarians were obese. Hence the incidence of obesity was found to be significantly higher in those adolescents who ate meals outside home ${ }^{5}$.

Most of the adolescentsts during their mealtime eat junk food and get addicted to its taste, but it has low nutritive value and high calories, which results in obese children. Junk foods are also laced with colours which are often inedible, carcinogenic and harmful to the body which can affect the digestive system. Food colouring can cause hyperactivity and lapses of concentration in children, resulting in a child with learning disabilities ${ }^{6}$.

Among 341 young working adults regarding attitude towards the health of junk food, the participants gave overweight and obesity (44.3\%) as their main concern, followed by heart disease (19.2\%) and cancer $(18.6 \%)$. Although these findings were not significant, substantially more participants in the higher socioeconomic group were concerned about diabetes $(17.0 \%)$, while participants in the low socioeconomic group (23.1\%) and middle socioeconomic group (19.4\%) were concerned about heart disease ${ }^{7}$.
Among 300 students, $72 \%$ prefer junk food for tastiness than home cooked food. (Bake, 2012) So, the new generation is more attracted to junk food items, these replace the other healthier choices such as homemade fresh foods which directly affects health as it may lead to obesity and other diseases in the future.

The objectives of this study were to assess the junk food consumption habits among secondary level school students, to assess its influencing factors and the pattern of junk food consumed amongst them

\section{Material and Methods}

This was a descriptive cross-sectional research design used to assess the influencing factors of junk food consumption and its pattern among school adolescence. The study populations were the students of class 9 and 10 of Bishow Prakash Higher Secondary School, Bharatpur-15, Chitwan. Cluster random sampling technique was used. Out of five sections of class nine and ten, three section were chosen and total students for selected section were taken as study sample, for the convenience of the study. The sample size was determined according to sample size formula which was estimated up to 142 .

Inclusion Criteria: Those students were present in the class on the day of data collection and willing to participate in the study.

Semi-structure self-administered questionnaire was developed. The questionnaire was developed by researcher herself on the basis of review related literature, and seeking the opinion from subject experts on the basis of research objectives. The questionnaire was translated and administered in Nepali language by a Nepali teacher.

The questionnaire was divided into two parts: part first related to socio-demographic information and part two related to junk food pattern and influencing factors of junk food consumption.

The content validity of the instrument was maintained by developing the instrument on the basis of literature review and seeking the opinion from the research advisor.

Pre-test of the instrument was done among $10 \%$ of total sample i.e. $(n=14)$ in Shree Madhyamik Vidyalaya Dhaddaghari, Bharatpur-17 and necessary modification were done on the basis of pre-test finding.

Administrative approval was obtained from the concerned authorities of Bishow Prakash Higher Secondary School and Shree Madhyamik Vidyalaya 
Dhaddaghari after submitting the request from NPI College. The purpose of the study was explained to each participant.

Informed consent was obtained from each participant and their parents. Confidentiality was maintained by not disclosing the information by giving a code and by using the information only for the study purpose.

The collected data was checked, reviewed and organized for completeness and accuracy and then organized. All the collected data were analysed by using descriptive statistics with SPSS Version 20. Descriptive results were expressed as frequencies, percentage and mean and the important findings of the study were presented in the form of tables.

\section{Results}

Data obtained from 142 respondents were analysed according to objectives of the study by using descriptive statistics such as frequency, percentage and mean. In order to facilitate the interpretation, the analysed data was organized and presented in different tables

Table 1: Demographic Variables of Respondents $(n=142)$

\begin{tabular}{lcc}
\hline Variables & Frequency & Percentage \\
\hline Age (Mean age: 15.7) & & \\
\hline $13-15$ & 63 & 44.4 \\
\hline $16-20$ & 79 & 55.6 \\
\hline Sex & & \\
\hline Male & 66 & 46.5 \\
\hline Female & 76 & 53.5 \\
\hline Religion & & \\
\hline Hindu & 122 & 85.9 \\
\hline Buddhist & 17 & 12.0 \\
\hline Christian & 3 & 2.1 \\
\hline Cast & & \\
\hline Brahmin & 43 & 30.3 \\
\hline Chhetri & 35 & 24.6 \\
\hline Adivasi/Janajati & 50 & 35.2 \\
\hline Dalit & 14 & 9.9 \\
\hline Education of parents & & \\
\hline Literate & 134 & 94.4 \\
\hline Illiterate & 8 & 5.6 \\
\hline If literate, educational of mother & 38.0 \\
\hline Only read and write & 54 & 19.0 \\
\hline Primary education & 27 & 30.3 \\
\hline $\begin{array}{l}\text { Secondary level } \\
\text { education }\end{array}$ & 43 & \\
\hline $\begin{array}{l}\text { Higher secondary level } \\
\text { education }\end{array}$ & 10 \\
\hline
\end{tabular}

\section{If literate, educational status of father}

\begin{tabular}{lcc} 
Only read and write & 45 & 31.7 \\
\hline Primary education & 21 & 14.8 \\
\hline $\begin{array}{l}\text { Secondary level } \\
\text { education }\end{array}$ & 48 & 33.8 \\
\hline $\begin{array}{l}\text { Higher secondary level } \\
\text { education }\end{array}$ & 18 & 12.7 \\
\hline Bachelor and above & 2 & 1.4 \\
\hline $\begin{array}{l}\text { Father's occupation } \\
\text { Agriculture }\end{array}$ & 39 & 27.5 \\
\hline Business & 23 & 16.2 \\
\hline Labour & 19 & 13.4 \\
\hline Foreign employee & 59 & 41.5 \\
\hline Teacher & 2 & 14 \\
\hline Family income & & \\
\hline$<2500$ & 7 & 4.9 \\
\hline $2501-5000$ & 12 & 8.5 \\
\hline $5001-10000$ & 27 & 19.0 \\
\hline $10001-15000$ & 30 & 21.1 \\
\hline$>15001$ & 66 & 46.5 \\
\hline
\end{tabular}

Majority of respondents $(53.5 \%)$ were in the age group of $16-20$ years and $44.4 \%$ respondents were in the age group of $13-15$ years. Mean age was 15.74 . Regarding sex $53.5 \%$ respondents were female and $46.5 \%$ were male. Religion-wise $85.9 \%$ were Hindu and $2.1 \%$ were Christian. Caste variable showed $35.2 \%$ Janajati and $9.9 \%$ Dalit. Educational status of the parents revealed $94.4 \%$ to be literate and $5.6 \%$ illiterate. Majority of respondent's fathers $(41.5 \%)$ were foreign employed and $1.4 \%$ were teachers. Income showed the majority of $(46.5 \%)$ from the family having monthly income Rs. $>15001$ and $4.9 \%$ were belonged from the family having income Rs. $<2500$ per month.

Table 2: Respondents' Awareness Regarding Junk Food $(n=142)$

\begin{tabular}{lcc}
\hline Variables & Frequency & Percentage \\
\hline Homemade foods in Tiffin & & \\
\hline Yes & 0 & 0 \\
\hline No & 142 & 100.0 \\
\hline Awareness & \\
\hline Yes & 113 & 79.6 \\
\hline No & 29 & 20.4 \\
\hline Place where food consumed mostly & \\
\hline Home & 12 & 8.5 \\
\hline School & 130 & 91.5 \\
\hline Allowed in school & & \\
\hline Yes & 142 & 100.0 \\
\hline No & 0 & 0 \\
\hline
\end{tabular}


It was revealed that awareness regarding junk food; none of the respondents $(100 \%)$ brought homemade food for their Tiffin. Majority of them (79.6\%) were aware of the meaning of junk food. The area where food was mostly consumed: $91.5 \%$ consumed junk food in school and $8.5 \%$ consumed it at home. All of the respondents $(100 \%)$ were however allowed to consume junk food in their school.

Table 3: Showing pattern of Junk Food consumption $(n=142)$

\begin{tabular}{lcc}
\hline $\begin{array}{l}\text { Consumed Junk Food } \\
\text { pattern** }\end{array}$ & Frequency & Percentage \\
\hline Biscuits* & 136 & 95.8 \\
\hline Ice-cream* $^{*}$ & 93 & 65.5 \\
\hline Donuts $^{*}$ & 132 & 93.0 \\
\hline Chat pat* $^{*}$ & 142 & 100.0 \\
\hline Panipuri* $^{*}$ & 138 & 97.2 \\
\hline Noodles & 142 & 100.0 \\
\hline Chapatti $^{*}$ & 26 & 18.3 \\
\hline Chocolates $^{*}$ & 131 & 92.3 \\
\hline Cold drinks $^{*}$ & 93 & 65.5 \\
\hline
\end{tabular}

${ }^{*}$ Correct response ${ }^{* *}$ Multiple response

All respondents (100\%) consumed noodles and chat pat, $97.2 \%$ consumed panipuri, $95.8 \%$ consumed biscuits, $93.0 \%$ consumed doughnuts, $92.3 \%$ consumed chocolates, $65.5 \%$ consumed ice-cream and cold drinks and $18.3 \%$ consumed chapatti.

Table 4: Showing Frequently Consumed Junk Food $(n=142)$

\begin{tabular}{lcc}
\hline $\begin{array}{l}\text { Frequently Consumed } \\
\text { Junk Food }\end{array}$ & Frequency & Percentage \\
\hline Biscuits & 19 & 13.4 \\
\hline Doughnuts & 8 & 5.6 \\
\hline Chat pat & 51 & 35.9 \\
\hline Pani-puri & 10 & 7.0 \\
\hline Noodles & 47 & 33.1 \\
\hline Chocolates & 7 & 4.9 \\
\hline
\end{tabular}

Type of junk food consumed was; $35.9 \%$ consumed chat-pat, $33.1 \%$ frequently consumed noodles, $13.4 \%$ frequently consumed biscuits, $7 \%$ consumed panipuri, $5.6 \%$ consumed doughnuts and $4.9 \%$ frequently consumed chocolates.

Table 5: Consumed Time and Frequency of Junk Food within two days amongst respondents $(n=142)$

\begin{tabular}{lcc}
\hline Variable & Frequency & Percentage \\
\hline Consumed timing & & \\
\hline Morning & 2 & 1.4 \\
\hline Afternoon & 129 & 90.8 \\
\hline
\end{tabular}

\begin{tabular}{lcc} 
Evening & 10 & 7.0 \\
\hline Night & 1 & 0.7 \\
\hline Consumed frequency within & 2 days & \\
\hline I didn't eat & 5 & 3.5 \\
\hline $4-6$ times & 19 & 13.4 \\
\hline Once a day & 58 & 40.8 \\
\hline Twice a day & 60 & 42.3 \\
\hline
\end{tabular}

Timings of junk food mostly consumed; the majority (90.8\%) consumed junk food at afternoon and $0.7 \%$ consumed at night. Concerning consumed frequency within 2 days, $42.3 \%$ of consumed junk food twice a day and $3.5 \%$ didn't consume junk food.

Table 6: Influencing Factors for Junk Food Consumption $(n=142)$

\begin{tabular}{lcc}
\hline Influencing Factors ** & Frequency & Percentage \\
\hline It tastes better* $^{*}$ & 128 & 90.1 \\
\hline It is faster $^{*}$ & 63 & 44.4 \\
\hline Peer influences $^{*}$ & 45 & 31.7 \\
\hline TV advertisement* & 22 & 15.5 \\
\hline Nothing else is available $^{*}$ & 42 & 29.6 \\
\hline It is free of cost & 2 & 1.4 \\
\hline
\end{tabular}

${ }^{*}$ Correct response ${ }^{* *}$ Multiple responses

Influencing factors for junk food consumption; majority $(90.1 \%)$ consumed junk food as it tastes better, $44.4 \%$ consumed as it is faster, $31.7 \%$ consumed junk food as peer influence, $29.6 \%$ because nothing else was available, $15.5 \%$ consumed it as influenced by TV advertisement and minority of respondents (1.4\%) thought it is free of cost.

Table 7: Money and affordability to buy Junk Food $(n=142)$

\begin{tabular}{lcc}
\hline Variable & Frequency & Percentage \\
\hline Person who provided money & & \\
\hline Mother & 79 & 55.6 \\
\hline Father & 46 & 32.4 \\
\hline Brother/sister & 17 & 12.0 \\
\hline Affordability & & \\
\hline Yes & 48 & 33.8 \\
\hline No & 94 & 66.2 \\
\hline
\end{tabular}

Person who provided money to buy junk food: most of the respondent's mother (55.6\%) gave money to buy junk food and $12 \%$ respondent's brother/sister gave money to them. Concerning affordability to buy junk food $66.2 \%$ respondents were unable to afford junk food. 
Table 8: Knowledge of Major Health Risks Associated with Poor Eating Habits $(n=142)$

\begin{tabular}{lcc}
\hline $\begin{array}{l}\text { Knowledge of major } \\
\text { health risk with poor } \\
\text { eating habit }\end{array}$ & Frequency & Percentage \\
\hline $\begin{array}{l}\text { Understood about health } \\
\text { risk }\end{array}$ & 77 & 54.2 \\
\hline $\begin{array}{l}\text { Heard but not known about } \\
\text { health risk }\end{array}$ & 45 & 31.7 \\
\hline $\begin{array}{l}\text { Known about poor eating } \\
\text { habits unknown about risks }\end{array}$ & 18 & 12.7 \\
\hline \begin{tabular}{l} 
Totally unknown \\
\hline
\end{tabular} & 2 & 1.4 \\
\hline
\end{tabular}

Awareness regarding major health risks associated with junk food consumption, most (54.2\%) understood what they mean and $1.4 \%$ were unaware if there were any health risks associated with junk food consumption.

\section{Discussion}

Junk food is energy dense food with high amount of refined sugar, white flour, trans-fat, polyunsaturated fat, salt, numerous additives and low nutrient value in terms of protein, fibre, vitamin and mineral content ${ }^{1}$. Our purpose of the study is to find out about the junk food consumption habits of the secondary level students and the pattern of junk foods used. The finding shows that 85.9\% respondents were Hindus and $2.1 \%$ Christians which was similar to the result of Kotecha et al. ${ }^{8}$ which showed $93 \%$ Hindus and $2 \%$ of respondents Christians. Children of the parents involved in farming (27.5\%) were more than doing business $(16.2 \%)$ whereas Bake ${ }^{10}$, showed $7 \%$ respondent's fathers were farmers and $37 \%$ of the respondent's fathers had their own business.
Our finding of the pattern of junk food consumed, maximum were chat pat consumer, followed by biscuit, chocolate, ice cream and cold drinks which was similar with the study done by Kotecha et $\mathrm{al}^{8}$ and Kigaru et $\mathrm{al}^{12}$. The maximum number of students have a variety of junk food for in their school which is low in nutrient value and high calorie often added with colours. Food colouring can cause hyperactivity and lapses of concentration in children resulting in learning disability ${ }^{6}$.

Children usually get addicted to the food containing sweetening agents and food preservatives that are addictive to nature so they deny eating homemade foods and skip their meals as well ${ }^{1}$. This study showed that students preferred junk food for taste, fast availability and peer influences which were also shown in the study done by Bake ${ }^{10}$ and Joseph et al $^{11}$.

In this, students consumed junk food twice a day $(42.3 \%)$, once a day $(40.1 \%)$ and 4-6 times within last two days $(13.4 \%)$ whereas in the similar study done by Joseph et al ${ }^{11}$ students consumed junk food almost every day. Hence the frequency of the junk food consumption also supplements in causing harm to the body.

\section{Conclusion}

All children consumed junk food in a regular basis; the majority preferred it for taste and some as influenced by advertisements. Only half of them were aware of health risks associated with poor eating habits. Thus, there is a great need to maintain a practice of healthy eating habits among the adolescence in order to decrease the health risk associated with eating frequent junk food.

\section{References}

1. Kausik J, Narang M, Parakh A. Fast food consumption in children. Indian Pediatr 2011;48(2):97-110.

2. Goyal A, Singh NP. Consumer perception about fast food in India: an exploratory study. British Food $J$ 2007;109(2):182-195.

3. Thiruselvakumar D, Sinuvasan K, Chakravarthy R, Venkatesh E. Int J Sci Res Pub 2014;4(4):131-134.

4. Datar A, \& Nicosia N. Junk Food in Schools and Childhood Obesity. J Policy Anal Manage 2012: 31(2): 312-337. DOI: 10.1002/pam.21602

5. Aggarwal T, Bhatia R.C, Singh D, Sobti PC. Prevalence of Obesity and Overweight in Affluent Adolescents from Ludhiana, Punjab. Indian Pediatr 2008 Jun;45(6):5002.
6. Arya G, Mishra S. Effects of junk food and beverages on adolescent's health. J Nurs Health Sci (IOSRJNHS) 2013;1(6):26-32

7. Van Zyl M.K, Nutr M, Steyn NP, Marais ML. Characteristics and factors influencing fast food intake of young adult consumers in Johannesburg, South Africa. 2010;23(3):124-30

8. Kotecha PV, Patel SV, Baxi RK, Mazumdar VS, Misra S, Mehta KG et.al. Dietary Pattern of School going Adolescents in Urban Baroda, India. J Health Popul Nutr 2013;31(4):490-6.

9. Majabadi HS, Solhi M, Montazeri A, Shojaeizadeh D, Nejat S, Farahani FK. Factors Influencing FastFood Consumption Among Adolescents in Tehran: A Qualitative Study. Iran Red Crescent Med J 2016;18(3):e23890. 
10. Bake, A. A Study of on Urban Food Habits of Children and Adolescents of Kathmandu Valley. [Online] 2012 [Retrieved on August 2 2016]. Available from http:// nepaknol.net/recphec/resources/filestore/9/3/9_10ac6 5220079705/939_000a7062afc5f77.pdf

11. Joseph N, Nil M, Rai S, Y.P, R, Kotia S.M, Ghosh T \& Singh M. Fast Food Consumption Pattern and Its
Association with Overweight Among High School Boys in Mangalore City of Southern India. J Clin Diag Res 2015;9(5):13-17.

12. Kigaru D, Loechl, C, Moleah T, Mutie, CW. Ndungu, ZW. Nutrition knowledge, attitude and practices among urban primary school children in Nairobi City, Kenya-a KAP study. BMC Nutrition 2015;44(1):1-8. DOI: 10.1186/s40795-015-0040-8. 